\title{
Chemical Activation of Syrian Sponge Coke
}

\author{
Hassan Al-Haj Ibrahim* \\ Al-Baath University, Syria
}

Submission: September 20, 2017; Published: October 16, 2017

*Corresponding author: Hassan Al-Haj Ibrahim, Al-Baath University, Syria, Email: sanjim84@yahoo.com

\begin{abstract}
Syrian sponge coke activated by treatment with molten potassium hydroxide is used in the adsorption of naphthalene from water. Some of the factors that are expected to affect the process of adsorption are also investigated. The results obtained indicate that the adsorption of naphthalene by activated coke can be represented by the Langmuir and Freundlich equations.
\end{abstract}

Keywords: Activated carbon; Petroleum coke; Adsorption; Naphthalene

\section{Introduction}

Water pollution by aromatic compounds is a serious problem. Although aromatic compounds are in general nonpolar compounds, their polarity is greater than that of aliphatic compounds with similar number of carbon atoms and aromatic compounds are therefore less volatile and easier to dissolve in water with a very low threshold of detectability by taste or in water. In fact, few micrograms of aromatic compounds in a liter of water are sufficient to make the water undrinkable or less suitable for drinking [1].

Polycyclic aromatic compounds are poisonous and possibly carcinogenic pollutants. They are, furthermore, semi volatile and semi stable and not easily disposed of or decomposed by living organisms. Their presence in water may also render ineffective the biological treatment of water. Crude oil often contains certain amounts of such compounds, particularly naphthalene and methyl naphthalene, which are released on incomplete combustion [2] or from coking and other plants. Analysis of sewage and used water often reveals their presence and their amounts in water are controlled in international water specifications [3]. In this study, naphthalene was used as an example of other polycyclic aromatic compounds because of its high content in used industrial waters.

Naphthalene (C10H8) is a bicyclic aromatic compound with an equivalent carbon number of 11.69. It is a white, volatile, crystalline solid that is easily sublimated at normal temperatures. It is normally used for cloth protection from bugs and insects. Its solubility in water is about $30 \mathrm{mg}$ per liter, and water may be considered polluted if its naphthalene content is greater than $0.1 \mathrm{mg} /$ liter [1]. Exposure to naphthalene may have adverse effects on red blood cells and may cause sickness, diarrhea, nausea and jaundice. Naphthalene is a carcinogenic substance according to the International Cancer Research Agency. Naphthalene powder may also form with air an explosive mixture.

Current research indicates that adsorption is one of the most effective methods for treatment of water polluted with aromatic compounds, which are easily adsorbed. These include naphthalene, polycyclic aromatics, insecticides, herbicides and high molecular-weight compounds such as dyes, gasoline and amines. Most research on the adsorption of polycyclic compounds has been concerned with adsorption in the gaseous phase with much less work on adsorption form aqueous solutions [4,5]. Adsorption from complex multi-component aqueous solutions is much more complicated than adsorption from the gaseous phase. This is mainly due to the possible interactions between the different components and their effect on the adsorbent's selectivity in the adsorption of the dissolved substances in preference to the adsorption of the solvent. This is especially apparent in dilute solutions with a high solvent concentration as in the case of solutions of polycyclic compounds in water.

Carbon adsorption is an effective water treatment method. It was used from ancient times in water treatment. Arabs in 


\section{Recent Advances in Petrochemical Science}

the middle Ages used some form of carbon to purify water, and when they had to drink turbid water they added some smoldering embers that would be extinguished in it [6]. In China, a chemical plant exploded a few years ago and large amounts of benzene leaked into the Sing Hwa Jiang River which formed a slick that extended for forty miles. The best method selected for cleansing the river water was by dropping activated carbon in the river.

Activated carbon is one of the best materials that may be used in the adsorption and elimination of contaminants where a large number of pollutants may be adsorbed at different temperatures. Activated carbon may also be used for separation of bacteria, viruses and intractable hydrocarbons that are difficult to separate [7]. Activated carbon is a porous substance with pores that are different in size and shape. Pores may be divided in general into two classes: rectangular pores of different width and circular pores of different diameters. This classification was first suggested by Dubinin and was later generally adopted by chemists. Pores in activated carbon are divided into micropores, mesopores and macropores. Macropores have diameters greater than 50 nanometers and can be as great as a few thousands of nanometers. Macropores have little effect on the carbon surface area, their surface area being less than $0.5 \mathrm{~m}^{2} / \mathrm{g}$. Macropores, however, form channels through which adsorbate particles may travel to the mesoand micropores. Mesopores have diameters that vary between 2 and 50 nanometers. They make up about $5 \%$ of the surface area of the activated carbon. Micropores, on the other hand, make up most (about 95\%) of the carbon surface area. Their diameters are less than 2 nanometers. Work by a number of researchers indicates that it is macropores with diameters less than one nanometer that are mainly responsible for adsorbing naphthalene molecules from their aqueous solution [4].

Activated carbon is a non-polar hydrophobic material that is more attracted to oils and hydrocarbons than to water. It is generally known that the adsorption of non-polar solutes is greater with non-polar adsorbates. The solvent, however, must be polar, such as water, in order for the molecules of the solute to be attracted more to the surface of the adsorbate than the solvent molecules. For this reason, activated carbon is easily attached to organic carbon dissolved in water in contrast to organic carbon dissolved in non-polar hydrocarbons [8]. Activated carbon particles can selectively adsorb hydrocarbon materials in preference to other materials, particularly largersized and non-polar particles such as aromatic compounds in general and polycyclic compounds such as naphthalene in particular. The explanation for the difference between the adsorption of polar and non-polar compounds and what occurs at the solid-liquid interface is not, however, straight forward. Most workers are of the opinion that adsorption of non-polar compounds is due to scattering forces whereas adsorption of polar compounds is due rather to the mutual interactions between the molecules of the adsorbent and the adsorbate
[9]. The ability of activated carbon to adsorb hydrocarbons dissolved in water depends on the diffusion of particles towards the outer surface of the carbon and their diffusion inside the pores. The force of attraction between the carbon and the adsorbed particles increases when the size of these particles approaches that of the pores, and when the size of the pores is just sufficient for admitting the adsorbed particles. The most important factors that affect adsorption by activated carbon include the nature of the chemical compounds considered singly or collectively, treatment time and temperature.

There are three basic methods for the separation of hydrocarbons dissolved in water, viz. filtration of larger-sized particles, deposit on the outside surface of the carbon particles and adsorption of lower-polarity hydrocarbons. The carbon adsorption effectiveness decreases with time as the carbon adsorbs more and more particles, and the carbon is said to be spent. Spent carbon may, however, be re-activated by heating to a high temperature, although the adsorption of aromatics by activated carbon is a non-reversible process as indicated by the large hysteresis between adsorption and desorption [1012]. On the other hand, adsorption may be made reversible and desorption easier by the use of special kinds of activated carbon.

\section{Petroleum Coke}

Activated carbon may be made from different materials such as coal, peat, bitumen, wood, biofuel, agricultural and other wastes [13]. Crude oil and particularly heavy asphaltbase crude oil may also be utilized for coke making. This socalled petroleum coke may in most cases be a low-value highsulphur product which makes it less suitable for direct use. The petroleum coke produced at the Homs Oil refinery is such a coke. Large amounts of this low-value coke accumulate to the west of the refinery, and it would be greatly beneficial if this coke could be used for making activated carbon which can then be used for water and other treatments. Previous work has demonstrated that the activated carbon thus produced may be used in the treatment of polluted water and that its performance is comparable to the commercially-available varieties of activated carbon. An overall separation efficiency of $86 \%$ was obtained when activated coke was used in the treatment of water polluted with oil products at the optimal conditions of temperature, time and adsorbate-to-coke ratio [14]. Activated coke may also be used in the treatment of gas for separation of acidic gases and $\mathrm{CO} 2$ in particular from natural gas [15] and for the separation of nitrogen and sulphur oxides and mercury vapor and other pollutants from other gases $[16,17]$.

Green petroleum coke has in general a low surface area. The BET method was used in this study for the measurement of the surface area of petroleum coke using liquid nitrogen at a low temperature $\left(-173{ }^{\circ} \mathrm{C}\right)$. The surface area measured for Syrian Petroleum coke varied between 0.04 and $0.23 \mathrm{~m} 2 / \mathrm{g}$. 


\section{Recent Advances in Petrochemical Science}

This variation is due to the fact that the samples used were mixtures of different types of petroleum coke.

Study of the different types of petroleum coke indicates that the porous sponge coke is most suited for activation and production of activated carbon suitable for adsorption purposes [18]. Previous work shows that the adsorption efficiency of sponge coke may be doubled as a result of activation [19]. Sponge coke is characterized by low oxygen content $(1.7 \%)$ compared to other types of coke, where the oxygen content may be as high as $3 \%$ [18]. Oxygen content has a significant effect on the efficiency of naphthalene adsorption from aqueous solutions. This was demonstrated in a study where it was pointed out that hydration clusters formed by oxygen impede the penetration of naphthalene into the inner pores [4], or they reduce their adherence to the carbon surface in cases of low naphthalene concentration [13].

Porous sponge coke samples were obtained from the coke heaps to the west of the Homs Refinery. The sponge coke samples were first dried in the laboratory atmosphere before being dried in an oven at a temperature of $110{ }^{\circ} \mathrm{C}$. The dried samples were then crushed and passed through $6 \mathrm{~mm}$ sieve and the coke powder was discarded. Results of the proximate and ultimate analyses of the coke samples are given in Table 1.

\section{Activation of Petroleum Coke}

There are two basic methods for coke activation, namely thermal activation using steam [14] and chemical activation. Both methods may be used for activation of petroleum coke and increasing its surface area and porosity. The two methods differ, however, in the size of the pores produced, where chemical activation increases for the most part micropores (with diameters less than 2 nanometers) whereas thermal activation increases larger-size pores. It was suggested by some researchers that this difference may be explained by the gaseous products of chemical activation which tend to increase porosity [13]. In general, chemical activation is the preferred method for coke activation and increasing its surface area and the number of micropores as well as for the separation of mineral matter from it $[11,20]$. Chemical activation may be carried by different methods including heating with potassium or sodium hydroxide $[21,22]$. Potassium hydroxide is generally preferred as it is possible by this means to increase greatly the surface area of the activated coke $\left(400-2,900 \mathrm{~m}^{2} / \mathrm{g}\right)[23,24]$. By treatment of petroleum coke with potassium hydroxide (ratio $1 / 10$ ), Otowa obtained an activated coke with a high surface area of $3,000 \mathrm{~m} 2 / \mathrm{g}$. Hydroxide Impregnation was found to be the main factor in coke activation [13].

In this work, activation of the coke was carried out by heating with potassium hydroxide. This was selected as the best method for obtaining activated coke with a high surface area. A small sample $(5 \mathrm{~g})$ of coke was placed in a porcelain crucible to which a proportionate amount of solid potassium hydroxide was added and the mixture heated in an oven at a temperature of $400{ }^{\circ} \mathrm{C}$ for four hours. The coke sample was then removed from the oven and washed with a liter of deionised water to remove all traces of the alkali and then placed in an Erlenmeyer to which half a liter of aqua regia was added. The mixture was then stirred and heated for 12 hours, after which it was again washed with deionised water on a Buchner funnel at reduced pressure to neutralize the filtrate $(\mathrm{pH}=7)$, and then heated in the oven at a temperature of $400{ }^{\circ} \mathrm{C}$ for a further four hours.

Table 1: Analysis of the porous sponge coke.

(1) Proximate analysis, air-dried basis.

(2) Ultimate analysis, Dry, ash-free basis.

\begin{tabular}{|c|c|}
\hline Ash (Wt. \%) & 0.2 \\
\hline Moisture (Wt. \%) & 0.3 \\
\hline Fixed Carbon (Wt. \%) & 0.9 \\
\hline Volatile Matter (Wt. \%) & 12.5 \\
\hline Sulphur (Wt. \%) & 7.7 \\
\hline Gross Calorific Value (Kj/Kg) & $34.8^{\prime} 10^{3}$ \\
\hline Real Density (G/Cm ${ }^{3}$ ) & 1.4 \\
\hline
\end{tabular}

\begin{tabular}{|c|c|}
\hline Carbon & 84.9 \\
\hline Hydrogen & 4.6 \\
\hline Nitrogen & 1.1 \\
\hline Oxygen & 1.7 \\
\hline Sulphur & 7.7 \\
\hline Carbon To Hydrogen Ratio $(\mathbf{W t})$. & 18.5 \\
\hline
\end{tabular}

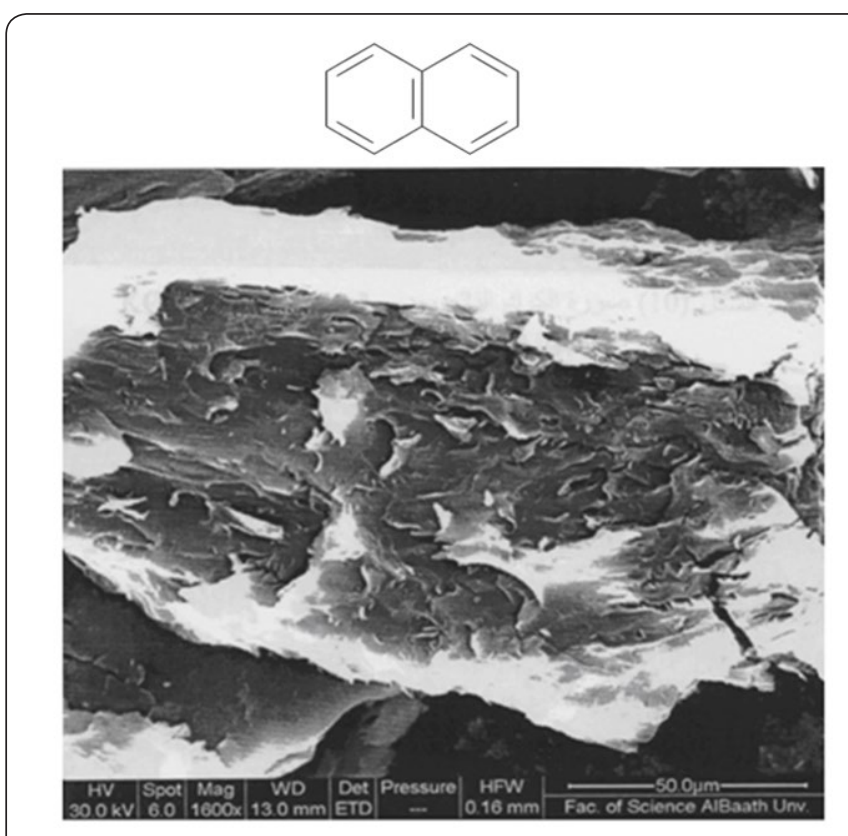

Figure 1: Fine structure of coke activated using a hydroxide ratio of 6 . 


\section{Recent Advances in Petrochemical Science}

After activation, the coke was dried at room temperature, crushed and passed through a $2 \mathrm{~cm}$ sieve to remove the larger coke pieces and the remainder was passed through a $6 \mathrm{~mm}$ sieve and the fine powder discarded. The surface area of the activated coke was then measured (Table 1). As can be seen from Table 2, the surface area increased with the ratio of the hydroxide used reaching a maximum at a hydroxide ratio of 6 , after which it dropped suddenly due most probably to the enlargement and merging of the micropores to form mesopores, as can be clearly seen in Figures 1 \& 2. Figure 1 shows the fine surface structure as seen through the electron microscope of the coke activated using a hydroxide ratio of 6 , where the size of the pores varied between 2 and 12 nanometers. Figure 2 shows the surface structure when a hydroxide ratio of 10 was used with the size of the pores increasing beyond 10 nanometers.

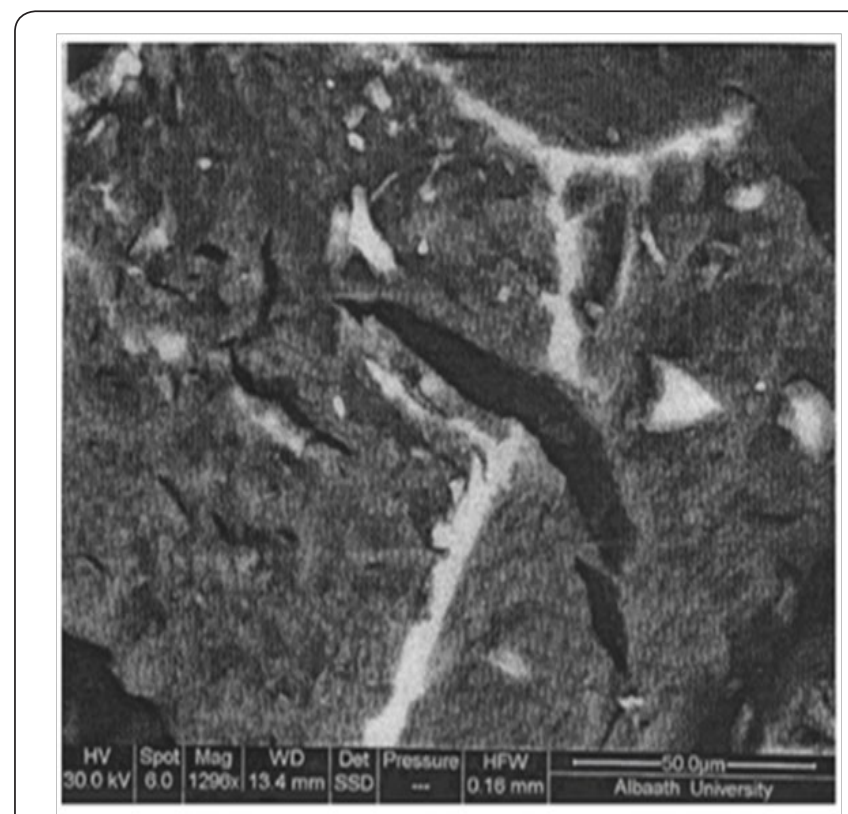

Figure 2: Fine structure of coke activated using a hydroxide ratio of 10 .

Table 2: Variation of the surface area of the activated coke with the ratio of hydroxide used.

\begin{tabular}{|c|c|}
\hline Potassium Hydroxide/Coke Ratio (Wt.) & Surface Area $\mathbf{M}^{\mathbf{2}} \mathbf{G}$ \\
\hline 1 & 220 \\
\hline 2 & 540 \\
\hline 4 & 850 \\
\hline 6 & 1500 \\
\hline 8 & 510 \\
\hline 10 & 360 \\
\hline
\end{tabular}

The increase in the surface area of activated coke is closely related to the elimination of sulphur and other inorganic matter [11] particularly at the sites at which such elimination takes place. Breaking the sulphur-carbon bonds lead to the formation of pores and sites where activation may take place. Analysis of activated coke shows that its sulphur content decreased after activation to less than $1 \%$ (Table 3). The content of heavy elements, especially vanadium, decreased also (Table 4).

Table 3: Sulphur content in the activated coke.

\begin{tabular}{|c|c|}
\hline $\begin{array}{c}\text { Potassium Hydroxide/Coke Ratio } \\
\text { (Wt.) }\end{array}$ & Sulphur Content (Wt.\%) \\
\hline 1 & 0.9 \\
\hline 2 & 0.7 \\
\hline 4 & 0.5 \\
\hline 6 & 0.2 \\
\hline 8 & 0.2 \\
\hline 10 & 0.2 \\
\hline
\end{tabular}

Table 4: Contents of heavy elements in coke (PPM).

\begin{tabular}{|c|c|c|}
\hline Element & Green Coke & Activated Coke \\
\hline Vanadium & 740 & 8 \\
\hline Nickel & 240 & 62 \\
\hline Calcium & 210 & 105 \\
\hline Iron & 42 & 26 \\
\hline
\end{tabular}

For the adsorption experiments, the optimum hydroxide ratio was used for the activation of the coke (Table 2), where the surface area increased to $1,500 \mathrm{~m}^{2} / \mathrm{g}$, a value which is greater than the value obtained on thermal activation [14]. It is also greater than the value for the commercially available active carbons, which varies between 950 and $1150 \mathrm{~m}^{2} / \mathrm{g}$.

Naphthalene Adsorption

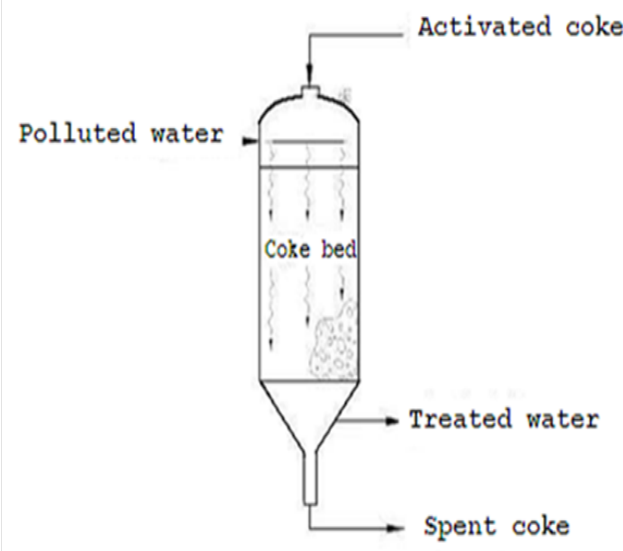

Figure 3: Layout of adsorption experiments.

Water specimens polluted with the required amount of naphthalene were prepared by adding deionised water to the solution of naphthalene in ethanol. The specimens prepared had a $\mathrm{pH}$ value in the range 7-8. The adsorption experiments were carried out at constant temperature $\left(25^{\circ} \mathrm{C}\right)$ and atmospheric pressure with a residence time of three hours. The choice of the residence time was based on results of previous work which indicated that the naphthalene concentration stabilizes after about three hours [13]. A series of experiments were 


\section{Recent Advances in Petrochemical Science}

conducted on one litre of water with different concentrations of naphthalene $(2.5-30 \mathrm{mg} / \mathrm{litre})$ using different amounts of activated coke (5-15g) (Figure 3). The coke used was granular as previous work indicated the inefficiency of using coke powder and also for the possibility of granular coke reactivation in contrast to powdered coke.

Water may be treated in either of two methods, namely by stirring in which powdered coke is added to the water and the mixture is stirred and by filtration where the water is made to flow over coke granules. The filtration method was used in this work because it was thought to be easier and in order to avoid possible flocculation of the coke granules as a result of stirring in water and the consequent loss of their efficacy. Although the filtration method has its disadvantages chiefly due to the accumulation of the adsorbate at the inlet side in contrast to the outlet side, these may be compensated for by increasing the amounts of coke and the residence time.

In the adsorption experiments, the prepared water specimens were made to flow over the coke bed, and the spent coke was washed with distilled water. The treated water was filtered and carbon tetrachloride was added to the filtrate which was separated into two layers: an organic layer at the top containing the carbon tetrachloride and the naphthalene and a lower aqueous layer. The two layers were then separated using a separation funnel and the percentage of the naphthalene in the organic layer was determined by liquid chromatography (GC mass). This represents the residual naphthalene in the water that has not been adsorbed, from which the adsorption efficiency of the coke was estimated.

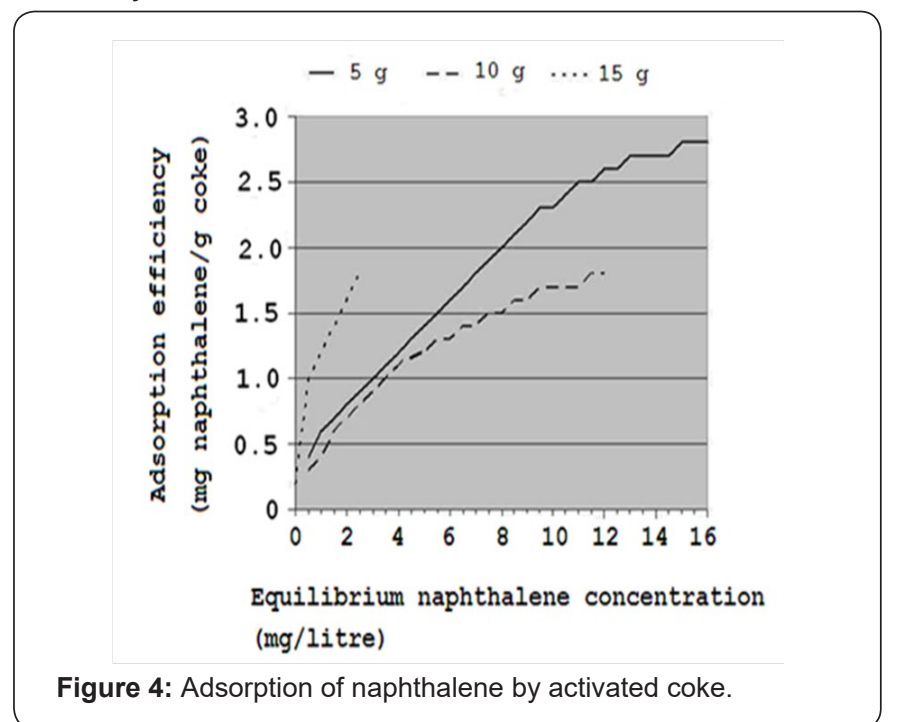

The efficiency of naphthalene adsorption in relation to naphthalene concentration in water and the amount of coke used is shown in Table 5 (Figure 4), from which it is apparent that the adsorption efficiency increases with increasing amount of coke and lower concentration of naphthalene. These results are in general agreement with previous results obtained with the adsorption of monocyclic aromatic compounds [25] and the adsorption of naphtha [14].

Table 5: Variation of adsorption efficiency with naphthalene concentration and amount of coke used.

\begin{tabular}{|c|c|c|c|}
\hline $\begin{array}{c}\text { Naphthalene } \\
\text { Concentration }\end{array}$ & \multicolumn{3}{|c|}{ Adsorption Efficiency } \\
\hline Mg/Litre & $\begin{array}{c}\text { Amount of } \\
\text { Coke = 5G }\end{array}$ & $\begin{array}{c}\text { Amount of } \\
\text { Coke = 10G }\end{array}$ & $\begin{array}{c}\text { Amount of } \\
\text { Coke = 15G }\end{array}$ \\
\hline 2.5 & 80 & 88 & 100 \\
\hline 5 & 74 & 84 & 99 \\
\hline 10 & 60 & 74 & 99 \\
\hline 15 & 57 & 73 & 97 \\
\hline 20 & 55 & 68 & 92 \\
\hline 25 & 52 & 66 & 92 \\
\hline 30 & 47 & 60 & 92 \\
\hline
\end{tabular}

The molecular size of the aromatic compound is an important factor in the adsorption by active carbon. Previous work shows that the efficiency of toluene adsorption is greater by a ratio varying between 4 and $13 \%$ than the efficiency of benzene adsorption [25]. This is probably due to the size difference between the molecules of the two compounds [26]. It was therefore expected that the efficiency of naphthalene adsorption would be even greater than the adsorption efficiency of these two compounds, something which was demonstrated in the present work.

The Langmuir equation is based on statistical and thermodynamic foundations. It was the first isotherm suggested for the study of adsorption equilibrium, although its agreement with experimental results is not always certain. One drawback of this equation is the assumption of the homogeneity of the energy of solid surface adsorption sites while ignoring side reactions between the adsorbed molecules. The Langmuir equation remains, however, the best equation for representing the adsorption of polycyclic aromatic compounds [27]. It makes possible a good representation of naphthalene adsorption. This is also in agreement with the representation of the adsorption of monocyclic aromatic compounds [9] and naphtha, particularly at lower concentrations of naphtha in water [14].

For the adsorption calculations using the Freundlich equation, values of the equilibrium concentration and adsorption efficiency are given in Table 6. Figure 5 shows graphic representation of the adsorption Freundlich equation. 


\section{Recent Advances in Petrochemical Science}

Table 6: Equilibrium and surface concentrations in naphthalene adsorption by activated coke.

\begin{tabular}{|c|c|c|c|c|c|}
\hline $\begin{array}{c}\text { Coke } \\
\text { Mass (G) }\end{array}$ & $\begin{array}{c}\text { Naphthalene } \\
\text { Concentration Mg/ } \\
\text { Litre }\end{array}$ & $\begin{array}{c}\text { Equilibrium } \\
\text { Concentration } \mathrm{Mg} / \\
\text { Litre }\end{array}$ & $\begin{array}{l}\text { Reciprocal Equilibrium } \\
\text { Concentration Litre/Mg }\end{array}$ & $\begin{array}{c}\text { Surface } \\
\text { Concentration4 } \\
\left(\mathrm{Mg} / \mathrm{M}^{2}\right) \times 10^{-3}\end{array}$ & $\begin{array}{c}\text { Reciprocal Surface } \\
\text { Concentration }\left(\mathrm{M}^{2} / \mathrm{Mg}\right) \\
\mathrm{X} 10^{3}\end{array}$ \\
\hline \multirow{7}{*}{5} & 2.5 & 0.5 & 2 & 0.3 & 3.3 \\
\hline & 5 & 1.3 & 0.8 & 0.5 & 2 \\
\hline & 10 & 4 & 0.3 & 0.8 & 1.3 \\
\hline & 15 & 6.5 & 0.2 & 1.1 & 0.9 \\
\hline & 20 & 9 & 0.1 & 1.5 & 0.7 \\
\hline & 25 & 12 & 0.1 & 1.7 & 0.6 \\
\hline & 30 & 16 & 0.1 & 1.9 & 0.5 \\
\hline \multirow{7}{*}{10} & 2.5 & 0.3 & 3.3 & 0.1 & 10 \\
\hline & 5 & 0.8 & 1.3 & 0.3 & 3.3 \\
\hline & 10 & 2.5 & 0.4 & 0.5 & 2 \\
\hline & 15 & 4 & 0.3 & 0.7 & 1.4 \\
\hline & 20 & 6.5 & 0.2 & 0.9 & 1.1 \\
\hline & 25 & 8.6 & 0.1 & 1.1 & 0.9 \\
\hline & 30 & 12 & 0.1 & 1.2 & 0.8 \\
\hline \multirow{7}{*}{15} & 2.5 & 0 & - & 0.1 & 10 \\
\hline & 5 & 0.1 & 10 & 0.2 & 5 \\
\hline & 10 & 0.2 & 5 & 0.5 & 2 \\
\hline & 15 & 0.5 & 2 & 0.7 & 1.4 \\
\hline & 20 & 1.7 & 0.6 & 0.8 & 1.3 \\
\hline & 25 & 2.1 & 0.5 & 1 & 1 \\
\hline & 30 & 2.5 & 0.4 & 1.2 & 0.8 \\
\hline
\end{tabular}

Table 7: Equilibrium concentration and efficiency of naphthalene adsorption by activated coke.

\begin{tabular}{|c|c|c|c|c|c|}
\hline Coke Mass (G) & $\begin{array}{c}\text { Naphthalene } \\
\text { Concentration Mg/ } \\
\text { Litre }\end{array}$ & $\begin{array}{c}\text { Equilibrium } \\
\text { Concentration } \mathrm{Mg} / \text { Litre }\end{array}$ & $\begin{array}{l}\text { Logarithm of } \\
\text { Equilibrium } \\
\text { Concentration }\end{array}$ & $\begin{array}{c}\text { Adsorption } \\
\text { Efficiency } \mathrm{Mg} / \mathrm{G}\end{array}$ & $\begin{array}{l}\text { Logarithm of } \\
\text { Adsorption } \\
\text { Efficiency }\end{array}$ \\
\hline \multirow{7}{*}{5} & 2.5 & 0.5 & -0.3 & 0.4 & -0.4 \\
\hline & 5 & 1.3 & 0.11 & 0.7 & -0.15 \\
\hline & 10 & 4 & 0.6 & 1.2 & 0.08 \\
\hline & 15 & 6.5 & 0.81 & 1.7 & 0.23 \\
\hline & 20 & 9 & 0.95 & 2.2 & 0.34 \\
\hline & 25 & 12 & 1.08 & 2.6 & 0.41 \\
\hline & 30 & 16 & 1.2 & 2.8 & 0.45 \\
\hline \multirow{7}{*}{10} & 2.5 & 0.3 & -0.52 & 0.2 & -0.7 \\
\hline & 5 & 0.8 & -0.1 & 0.4 & -0.4 \\
\hline & 10 & 2.5 & 0.4 & 0.8 & -0.1 \\
\hline & 15 & 4 & 0.6 & 1.1 & 0.04 \\
\hline & 20 & 6.5 & 0.81 & 1.4 & 0.15 \\
\hline & 25 & 8.6 & 0.93 & 1.6 & 0.2 \\
\hline & 30 & 12 & 1.08 & 1.8 & 0.26 \\
\hline \multirow{3}{*}{15} & 2.5 & 0 & - & 0.2 & -0.7 \\
\hline & 5 & 0.1 & -1 & 0.3 & -0.52 \\
\hline & 10 & 0.2 & -0.7 & 0.7 & -0.15 \\
\hline
\end{tabular}




\begin{tabular}{|c|c|c|c|c|c|}
\hline & 15 & 0.5 & -0.3 & 1 & 0 \\
\cline { 2 - 6 } & 20 & 1.7 & 0.23 & 1.2 & 0.08 \\
\cline { 2 - 7 } & 25 & 2.1 & 0.32 & 1.5 & 0.18 \\
\cline { 2 - 7 } & 30 & 2.5 & 0.4 & 1.8 & 0.26 \\
\hline
\end{tabular}

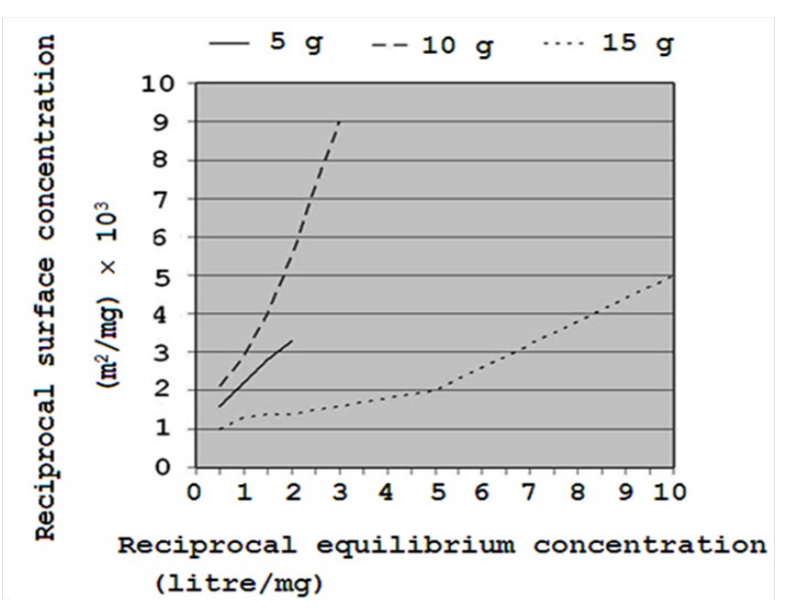

Figure 5: Application of Langmuir equation on the adsorption of naphthalene by activated coke.

Where:

$\mathrm{x}=$ Mass of adsorbate (Naphthalene) (mg)

$\mathrm{m}=$ Mass of adsorbent (Coke) $(\mathrm{g})$

= Adsorption efficiency (mg naphthalene/g coke)

$\mathrm{c}=$ equilibrium concentration of adsorbate (Naphthalene) in aqueous solution.

$\mathrm{n}$ and $\mathrm{K}$ are constants related to the nature of the adsorbate and adsorbent and adsorption temperature. A higher value of $n$ $(>1)$ indicates a higher adsorption efficiency (Table 7).

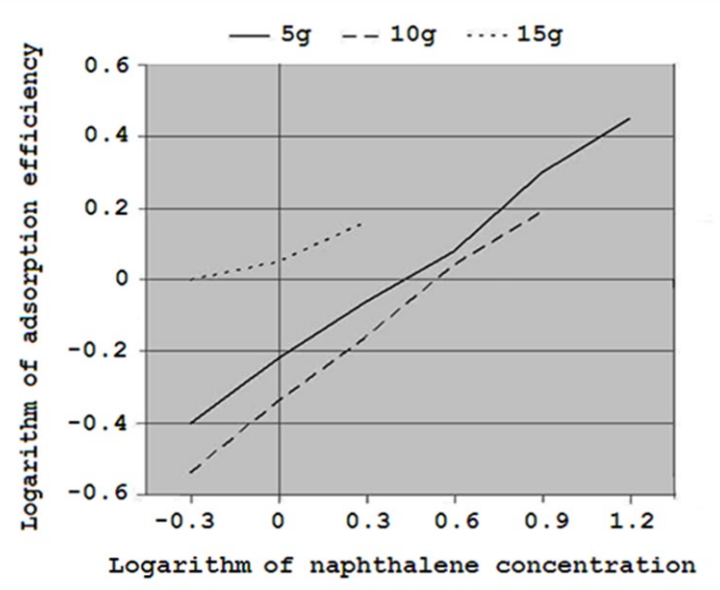

Figure 6: Application of Freundlich equation on naphthalene by activated coke.

The Freundlich equation is an empirically-based equation in which the energy of surface adsorption sites is assumed to be heterogeneous, which means that not all sites are considered active. The possibility of the reaction between the adsorbate molecules is also assumed. It has become common practice to apply this equation in different adsorption systems and particularly in chemisorptions because it gives more accurate results. As can be seen from Figure 6, agreement of the experimental results was good in the case of naphthalene in the concentration range considered especially when small amounts of coke $(5 \mathrm{~g})$ were used. The calculated value of the constant $\mathrm{n}$ is greater than 1 and it increases with increasing mass of coke used. The value of $\mathrm{n}$ was 2 when small amounts of coke were used and it increased to 6 when $15 \mathrm{~g}$ of coke were used. This is good evidence of the efficiency of using activated coke for the adsorption of naphthalene, which is better than the adsorption efficiency for naphtha and monocyclic compounds.

The results obtained in this study clearly indicate that it is possible to represent the adsorption of naphthalene by both the Langmuir and Freundlich equations with an almost perfect agreement as shown in Figure 5 \& 6 . Comparing these results with the results obtained for the adsorption of naphtha and monocyclic compounds, it is apparent that naphthalene adsorption by activated coke is more efficient and it is possible to treat water polluted with naphthalene and to achieve an almost complete separation of naphthalene from its aqueous solution using chemically-activated petroleum coke.

\section{References}

1. Petroleum products in drinking water (2005) World Health Organization, Switzerland.

2. Williams PT (1990) Sampling and analysis of polycyclic aromaticcompounds from combustion systems-a review. J Inst Energy 63: 2230.

3. Guidelines for drinking-water quality (2006) First addendum to recommendations ( $3^{\text {rd }}$ edn), World Health Organization, vol 1, Switzerland.

4. Ania CO, Cabal B, Pevida C, Arenillas A, Parra JB, et al. (2007) Effects of activated carbon properties on the adsorption of naphthalene from aqueous solutions. Applied Surface Science 253(13): 5741-5746.

5. Moreno-Castilla C (2004) Adsorption of organic molecules from aqueous solution on carbon materials. Carbon 42(1): 83-94.

6. Ibn Qayyim A (2007) Prophetic medicine (In Arabic), p. 387.

7. Ghose MK (2002) Complete physico-chemical treatment for coke plant effluents. Water Res 36(5): 1127-1134.

8. Cabal B, Ania CO, Parra JB, Pis JJ (2009) Kinetics of naphthalene adsorption on an activated carbon: Comparison between aqueous and organic media. Chemosphere 76(4): 433-438.

9. Radovic LR, Moreno-Castilla C (2000) Carbon materials as adsorbents in aqueous solutions. Chemistry and Physics of Carbon 27: 227-406. 
10. Tamon H (1996) Adsorption of aromatic compounds. J colloid and interface science 179(1): 25.

11. Lee SH, Cheong SC (2000) Chemical activation of high sulphur petroleum cokes by alkali metal compounds. Fuel processing technology 64(1-3): 141-153.

12. Tamon H, Okazaki m (1996) Desorption characteristics of aromatic compounds in aqueous solution on solid adsorbents. Journal of colloid and interface science 179(1): 181-187.

13. Cabal B, Budinova T, Ania CO, Tsyntsarski B, Parra JB, et al. (2009) Adsorption of naphthalene from aqueous solution on activated carbons obtained from bean pods. J Hazard Mater 161(2-3): 1150-1156.

14. Ibrahim AH, Nayif N (2005) Separation of oil products from polluted water using Syrian petroleum coke (In Arabic). Journal of Aleppo University Engineering series 46: 235-253.

15. Ibrahim AH, Nayif N (2007) Treatment of natural gas by adsorption using activated petroleum coke (In Arabic). Basil Alasad journal for engineering sciences 24: 53-71.

16. Tsuji K, Shiraishi I (1997) Combined desulfurization, denitrification and reduction of air toxics using activated coke. Fuel 76(6): 549-553.

17. Lee SH, Rhim YJ, Cho SP, Baek JI (2006) Carbon-based novel sorbent for removing gas-phase mercury. Fuel 85(2): 219-226.

18. Ibrahim AH (2005) Analysis of Syrian green delayed coke. Proceedings of the sixth Syrian egyptian conference on chemical and petroleum engineering, Homs, pp. 22-33.

19. Shawwa A, Smith D, Sego D (1999) Colour and chlorinated organic reduction in kraft pulp mill waste water using activated petroleum coke, sustainable forest management network of centres of excellence, MIT-6 Report, Canada.

This work is licensed under Creative Commons Attribution 4.0 Licens DOI: $10.19080 /$ RAPSCI.2017.03.555619
20. Illán MJ, García A, Salinas C, Linares A (1996) Activated carbons from spanish coals, 2 Chemical activation. Energy and Fuels 10(5): 11081114

21. Nurlatifah S, Pudiyanto TI (1996) Development technique in the activation process of petroleum coke, spring national meeting of the American chemical society, New Orleans, la (USA). Preprints of Papers, ACS, Division of Fuel Chemistry, 41(1).

22. Prinsloo FF, de Jager SGE (1997) Preparation of active carbon from coke by chemical activation. Proceedings American carbon soc, pp. 130-131.

23. Mitani S, Lee S, Yoon S, Korai Y, Mochida I, et al. (2004) Activation of raw pitch coke with alkali hydroxide to prepare high performance carbon for electric double layer capacitor. Journal of Power Sources 133(2): 298-301.

24. Mochida I, Yoon S, Qiao W (2006) KOH activation of needle coke to develop activated carbons for high-performance Edlc. Energy and Fuels 20(4): 1680-1684.

25. Ibrahim AH, Nayif $N$ (2009) Adsorption of monocyclic aromatic compounds from water using activated petroleum coke (In Arabic), Research Journal of Aleppo University, Engineering science series 69: 399-413.

26. Nouri S, Haghseresht F, Lu M (2002) Adsorption of aromatic compounds by activated carbon: effects of functional groups and molecular size. Adsorption science and technology 20(1): 1-15.

27. Luthy RG, Walters RW (1984) Equilibrium adsorption of polycyclic aromatic hydrocarbons from water onto activated carbon. Environ Sci Technol 18(6): 395-403.

\section{Your next submission with Juniper Publishers will reach you the below assets}

- Quality Editorial service

- Swift Peer Review

- Reprints availability

- E-prints Service

- Manuscript Podcast for convenient understanding

- Global attainment for your research

- Manuscript accessibility in different formats

( Pdf, E-pub, Full Text, Audio)

- Unceasing customer service

Track the below URL for one-step submission https://juniperpublishers.com/online-submission.php 